Tropical Journal of Pharmaceutical Research November 2017; 16 (11): 2727-2734

ISSN: $1596-5996$ (print); 1596-9827 (electronic)

(c) Pharmacotherapy Group, Faculty of Pharmacy, University of Benin, Benin City, 300001 Nigeria.

All rights reserved.

Available online at http://www.tjpr.org

Original Research Article

http://dx.doi.org/10.4314/tjpr.v16i11.21

\title{
Investigation of antibacterial and anti-cancer activities of Streptomyces sp SRF1 culture filtrate
}

\author{
Kusavadee Sangdee ${ }^{1}$, Benjaporn Buranrat ${ }^{1}$, Prapairat Seephonkai ${ }^{2,3}$, Nilawan \\ Surapong ${ }^{2}$ and Aphidech Sangdee ${ }^{4,5 *}$ \\ ${ }^{1}$ Biomedical Sciences Research Unit, Faculty of Medicine, Mahasarakham University, Muang District, Maha Sarakham 44000, \\ ${ }^{2}$ Nano Technology Research Unit, ${ }^{3}$ Center of Excellence for Innovation in Chemistry (PERCH-CIC), Department of Chemistry, \\ Faculty of Science, Mahasarakham University, Khamriang Sub-District, Kantarawichai District, Maha Sarakham 44150, \\ ${ }^{4}$ Department of Biology, ${ }^{5}$ Microbiology and Applied Microbiology Research Unit, Faculty of Science, Mahasarakham University, \\ Kantarawichai District, Maha Sarakham 44150, Thailand
}

*For correspondence: Email: aphidech.s@msu.ac.th

Sent for review: 7 December 2016

Revised accepted: 5 October 2017

\begin{abstract}
Purpose: To evaluate the antibacterial activity and cytotoxic effects of Streptomyces sp. SRF1 culture filtrate extract against breast cancer cell line.

Methods: The activity of the extract against Gram-positive and Gram-negative bacteria was initially screened by an agar-well diffusion method. Minimum inhibitory concentration (MIC) and minimum bactericidal concentration $(M B C)$ values were measured by broth microdilution method. Time-kill assays were also performed, and extract-induced morphological and ultrastructural changes to bacterial cells were investigated. Sulforhodamine $B$ (SRB) assay was performed to determine the cytotoxicity of the extract against the human breast cancer cell line, MCF-7.

Results: Antibacterial activity by the extract was detected against four strains of Gram-positive pathogens including one strain of methicillin-susceptible Staphylococcus aureus (MSSA) and 3 strains of methicillin-resistant Staphylococcus aureus (MRSA) - with low MIC and MBC values. This activity was bactericidal after $6 \mathrm{~h}$ exposure. Morphological alterations were detected on the cell surface of both MSSA and MRSA. The extract also inhibited MCF-7 cell growth with half-maximal concentration (IC $\left.{ }_{50}\right)$ of $211.67 \pm 33.95 \mu \mathrm{g} / \mathrm{mL}$ in $72 \mathrm{~h}$.

Conclusions: Streptomyces sp. SRF1 culture filtrate extract exhibits potent antibacterial and anticancer activities and thus, represents a potential source of antibacterial and anticancer drugs.
\end{abstract}

Keywords: Antibacterial activity, Anti-breast cancer, Staphylococcus aureus, Streptomyces sp. SRF1

Tropical Journal of Pharmaceutical Research is indexed by Science Citation Index (SciSearch), Scopus, International Pharmaceutical Abstract, Chemical Abstracts, Embase, Index Copernicus, EBSCO, African Index Medicus, JournalSeek, Journal Citation Reports/Science Edition, Directory of Open Access Journals (DOAJ), African Journal Online, Bioline International, Open-J-Gate and Pharmacy Abstracts

\section{INTRODUCTION}

Soil microorganisms are an interesting source of new bioactive compounds. Compounds produced by such organisms can be developed and used in both agriculture and medicine [1-2]. Actinomycetes are soil bacteria known to produce various novel bioactive compounds. They are present in nature in a wide range of habitats, exhibit considerable species diversity, and considerable diversity in terms of their morphology, physiology, and biochemical activities [3]. Bioactive compounds produced by actinomycetes can potentially be developed as novel therapeutic agents.

It was recently reported that $70 \%$ of all antibiotics in use were derived from actinomycetes bacteria [2], $75 \%$ of these from the genus Streptomyces [4-6]. Antibiotics derived 
from Streptomyces have antibacterial, antifungal, antioxidant, and antitumor activities [7-11]. For example, Lee et al [12] reported that the soil Streptomyces sp. AMLK-135 had activity against methicillin-resistant Staphylococcus aureus (MRSA). The mangrove soil Streptomyces pluripotens MUSC 137 is reported to have cytotoxic activity against human cancer cell lines [11]. Ethyl acetate extract from rock soil Streptomyces spp. ERI-3 has been shown to inhibit the growth of Staphylococcus aureus, $S$. epidermidis and Candida albicans [7]. Moreover, other soil Streptomyces spp. such as $S$. antibioticus, S. flaveolus and $S$. psammoticus have been shown to inhibit MRSA [13].

Previous studies in our laboratory have shown that Streptomyces sp. SRF1, an isolate from rice field soil in northeast Thailand, has in vitro antifungal activity against some economically important plant pathogens [14]. Crude mycelial and culture filtrate extracts of isolate SRF1 also inhibit growth of the foodborne pathogen Bacillus cereus, inducing its cells to become elongated and abnormal in shape, and to lyse [15]. However, no information is available on the activity of isolate SRF1 against other medically important pathogens or against human cancer cell lines. The aim of the present study, therefore, was to elucidate the effects of isolate SRF1 culture filtrate extract against human pathogenic bacteria by agar well diffusion, by the microdilution and time-kill methods, and by scanning electron microscopy (SEM). Cytotoxic activity of the extract was also investigated against human breast cancer cell line MCF-7 in this study using the SRB method.

\section{EXPERIMENTAL}

\section{Preparation of culture filtrate extract}

Seven-day old mycelial discs of Streptomyces $\mathrm{sp}$. isolate SRF 1 on half PDA were cut and placed into $50 \mathrm{~mL}$ of Arginine glycerol mineral salt (AGMS) medium before being incubated at $37^{\circ} \mathrm{C}$ with shaking at $250 \mathrm{rpm}$. After 14 days, the culture filtrate was collected and filtered through Whatman filter paper no. 1 before extraction with ethyl acetate by a liquid-liquid extraction method. The collected ethyl acetate layer was then evaporated under reduced pressure. The $50 \mathrm{mg}$ of yellow brown gum extract obtained was then re-suspended in $0.1 \mathrm{~mL}$ of methanol and adjusted to $50 \mathrm{mg} / \mathrm{mL}$ final concentration using distilled water, before being tested for activity against 16 pathogenic bacteria (Table 1) and the MCF-7 breast cancer cell line.

\section{Preliminary screening for antibacterial activity}

The activity of the culture filtrate extract was preliminary screened against 16 pathogenic bacteria by agar well diffusion method as described by Sangdee et al [16]. In brief, the 16 bacterial strains were cultured in $5 \mathrm{~mL}$ Mueller Hinton broth (MHB) and then they were incubated at $37^{\circ} \mathrm{C}$ with shaking at $250 \mathrm{rpm}$ for 3 $\mathrm{h}$. These were then adjusted to the 0.5 McFarland standard before being swabbed to the surface of Mueller Hinton agar (MHA). Next, wells were cut using a sterile cork borer, and 0.1 $\mathrm{mL}$ of culture filtrate extract was added to each well (final concentration of $50 \mathrm{mg} / \mathrm{mL}$ per well). After $16-18 \mathrm{~h}$ incubation $\left(37^{\circ} \mathrm{C}\right)$, the inhibition zones in each plate were measured. The antibiotics tetracycline and ciprofloxacin were used as reference standards at concentrations of $250 \mu \mathrm{g} / \mathrm{mL}$.

\section{Determination of minimum inhibitory concen- tration (MIC) and minimum bactericidal concentration (MBC)}

Next, the antibacterial activity of the culture filtrate was determined quantitatively. Because zones of inhibition were only detected against Staphylococcus aureus (MSSA) DMST 2933, MRSA DMST 4738, MRSA DMST 20651 and MRSA DMST 20654, MIC and MBC assays were only performed with these strains. MIC and MBC values of the extracts were determined using the microdilution method. Briefly, a -3 - $\mathrm{h}$ culture of test bacteria was adjusted to $4 \times 10^{6}-5 \times 10^{6}$ ) $\mathrm{CFU} / \mathrm{mL}$, and $10 \mu \mathrm{L}$ aliquots of this were added to the wells of a 96 - well polystyrene tray. Ninety microliter volumes of a diluted culture filtrate extract $(25,12.5,6.25,3.125,1.56,0.78,0.39$, 0.195 and $0.09 \mathrm{mg} / \mathrm{mL}$ ) in MHB were then added. A growth control well, and an uninoculated control well were included in each plate. Tetracycline at a concentration of 250 $\mu \mathrm{g} / \mathrm{mL}$ was used as a positive control. Wells with the lowest concentration of extract that remained clear after incubation were recorded as the MIC. $M B C$ values were determined by identifying the lowest concentration of extract capable of killing the test bacterium.

\section{Time-kill assay}

The bactericidal or bacteriostatic activity of the culture filtrate extract against MRSA DMST 20651 and MSSA DMST 2933 were performed by time - kill assays using a method modified from Thammawat et al [17]. Briefly, bacterial cultures in mid - logarithmic growth phase were standardized to the $0.5 \mathrm{McF}$ arland standard and 
then they were inoculated into several tubes of $\mathrm{MHB}$ containing an equal volume of various concentrations of extract $(0.78,0.39$ and 0.195 $\mathrm{mg} / \mathrm{mL}$ ) so as to give final concentrations of 0.39 $\mathrm{mg} / \mathrm{mL}$ (2x MIC), $0.195 \mathrm{mg} / \mathrm{mL}$ (1x MIC), and $0.09 \mathrm{mg} / \mathrm{mL}$ (0.5x MIC) extract, respectively. Test tubes of $\mathrm{MHB}$ without extract and $\mathrm{MHB}$ with $1 \mathrm{x}$ MIC tetracycline were included in each experiment. The final bacterial cell density was approximately $4-5 \times 10^{5} \mathrm{CFU} / \mathrm{mL}$. All tubes were incubated at $37^{\circ} \mathrm{C}$. At $0,2,4,6$ and $24 \mathrm{~h}$, time intervals, a small volume of bacterial suspension was removed, diluted, and spread onto the surface of MHA plates so that viable counts could be performed. The number of bacteria remaining in each sample was then plotted over time to determine the rate of killing. A three $\log _{10}$ reduction in bacterial numbers was considered to indicate bactericidal activity.

\section{Investigation of the effect of culture filtrate extract on bacterial cell morphology}

The effects of the culture filtrate extract on the surface characteristics and shape of MRSA DMST 20651 and MSSA DMST 2933 were investigated using a scanning electron microscope. Bacterial cells were incubated at 37 ${ }^{\circ} \mathrm{C}$ for $12 \mathrm{~h}$ with shaking at $250 \mathrm{rpm}$, then harvested, resuspended in $0.5 \mathrm{~mL} \mathrm{MHB}$, and inoculated into $0.5 \mathrm{~mL}$ of $1 \times$ MIC levels of the test extract. Samples were incubated at $37^{\circ} \mathrm{C}$ for $6 \mathrm{~h}$ with shaking at $250 \mathrm{rpm}$. Next, the bacterial cell pellets were collected and washed twice with $1 \mathrm{~mL}$ phosphate - buffered saline (PBS) before being fixed with $2.5 \%$ glutaraldehyde in $5 \%$ sucrose overnight at $4{ }^{\circ} \mathrm{C}$. Next, each cell pellet was dehydrated in an alcohol series. A total volume of $15 \mu \mathrm{L}$ of each sample was then applied to membranes. Dried samples were sputter - coated with gold and examined.

\section{Evaluation of anti-breast cancer cell line activity}

The anti-breast cancer cell line MCF-7 activity of the culture filtrate extract was elucidated using a SRB assay using a method modified from Buranrat et al [18] and Sangdee et al [19]. Briefly, MCF-7 cells were cultured in a 96 - well plate for $24 \mathrm{~h}$. After that, the cells were exposed to the culture filtrate extract at concentrations of 1 to $500 \mu \mathrm{g} / \mathrm{mL}$ for $24-72 \mathrm{~h}$. Next, the culture medium was removed before being fixed with 10 $\%$ cold trichloroacetic acid for $1 \mathrm{~h}$ at $4^{\circ} \mathrm{C}$. Then, the plates were washed five times with deionized water, air - dried, and $0.4 \%$ SRB in $1 \%$ acetic acid was added for $30 \mathrm{~min}$ at room temperature. Next, the plates were washed three times with-1
$\%$ acetic acid to remove any excess dye. After that, $200 \mu \mathrm{L}$ of $10 \mathrm{mM}$ Tris-base solution was added to solubilize the SRB dye within the cells. Next, the absorbance was measured at $540 \mathrm{~nm}$ using a micro-plate reader.

\section{Statistical analysis}

The data were analyzed using $t$-test. Significant differences between treatments and control group were considered significant at $p<0.05$. Statistical analyses was performed using SPSS statistical software (SPSS 14, SPSS Inc, IL, USA).

\section{RESULTS}

\section{Antibacterial activity of culture filtrate extract}

The activity of Streptomyces sp. SRF1 culture filtrate extract was investigated against 16 strains of human pathogenic bacteria. The extract inhibited the growth of 4 strains of Gram positive staphylococci, with large inhibition zone diameters compared to the control antibiotics tetracycline and ciprofloxacin. None of the test strains of Gram negative bacteria were affected (Table 1). Interestingly, MRSA DMST 20651 was resistant to ciprofloxacin and tetracycline at the tested concentration, but sensitive to the culture filtrate extract. MRSA DMST 20654 was also resistant to ciprofloxacin, but sensitive to the extract. Based on these results, only the 4 sensitive staphylococcal strains were selected for further antibacterial testing.

Minimum inhibitory concentration (MIC) and minimum bactericidal concentration (MBC)

The MICs and MBCs of the extract were determined by a broth microdilution method. The results show that the MICs and MBCs of the extract were quite low. MIC and MBC values of 0.195 and $0.390 \mathrm{mg} / \mathrm{mL}$, respectively, were determined for all four test strains, MSSA DMST 2933, MRSA DMST 4738, MRSA DMST 20651, and MRSA DMST 20654 (Table 1).

\section{Antibacterial activity}

Time-kill assays were performed to determine if the activity of Streptomyces sp. SRF1 culture filtrate extract is bacteriostatic or bactericidal. Bactericidal activity was defined as $a \geq 3 \log _{10}$ decrease in $\mathrm{CFU} / \mathrm{mL}$ of the bacterial population compared with the untreated control, while bacteriostatic activity was defined as a $<3 \log _{10}$ decrease in $\mathrm{CFU} / \mathrm{mL}$. The time kill profiles 
Table 1: Activity of Streptomyces sp. SRF1 culture filtrate extract against 16 strains of bacterial pathogen using the antibiotics ciprofloxacin and tetracycline as reference standards

\begin{tabular}{|c|c|c|c|c|c|}
\hline \multirow[b]{2}{*}{ Test bacterium } & \multicolumn{3}{|c|}{ Zone of inhibition (mm) } & \multicolumn{2}{|c|}{$\begin{array}{c}\text { Broth microdilution } \\
\text { method }\end{array}$} \\
\hline & $\begin{array}{c}\text { Culture } \\
\text { filtrate } \\
\text { extract } \\
(5 \mathrm{mg})\end{array}$ & $\begin{array}{c}\text { Ciprofloxacin } \\
(25 \mu \mathrm{g})\end{array}$ & $\begin{array}{c}\text { Tetracycline } \\
(25 \mu g)\end{array}$ & $\begin{array}{c}M I C \\
(m g / m L)\end{array}$ & $\begin{array}{c}M B C \\
(m g / m L)\end{array}$ \\
\hline S. aureus (MSSA) DMST 2933 & $36 \times 36$ & $25 \times 25$ & $32 \times 32$ & 0.195 & 0.390 \\
\hline S. aureus (MRSA) DMST 20651 & $37 \times 37$ & 0 & 0 & 0.195 & 0.390 \\
\hline MRSA DMST 4738 & $35 \times 35$ & $26 \times 26$ & $33 \times 33$ & 0.195 & 0.390 \\
\hline MRSA DMST 20654 & $31 \times 31$ & 0 & $22 \times 22$ & 0.195 & 0.390 \\
\hline V. cholerae (O1) DMST 9700 & 0 & $38 \times 38$ & $30 \times 30$ & ND & ND \\
\hline E. coli (EIEC) DMST 30545 & 0 & $20 \times 20$ & 0 & ND & ND \\
\hline E. coli O157:H7 DMST 12743 & 0 & $30 \times 30$ & $22 \times 22$ & ND & ND \\
\hline Sh. flexneri DMST 4423 & 0 & $33 \times 33$ & 0 & ND & ND \\
\hline Sh. flexneri DMST 17569 & 0 & $35 \times 35$ & 0 & ND & ND \\
\hline S. Typhi DMST 22842 & 0 & $33 \times 33$ & 0 & ND & ND \\
\hline S. Typhi DMST 16122 & 0 & $34 \times 34$ & $28 \times 28$ & ND & ND \\
\hline Sh. dysenteriae DMST 15110 & 0 & $33 \times 33$ & $20 \times 20$ & ND & ND \\
\hline S. Typhimurium ATCC 14028 & 0 & $31 \times 31$ & $26 \times 26$ & ND & ND \\
\hline Ps. aeruginosa ATCC 27853 & 0 & $25 \times 25$ & 0 & ND & ND \\
\hline Ps. aeruginosa & 0 & $25 \times 25$ & 0 & ND & ND \\
\hline K. pneumonia & 0 & $30 \times 30$ & $25 \times 25$ & ND & ND \\
\hline
\end{tabular}

MIC, minimum inhibitory concentration; MBC, minimum bactericidal concentration; ND, not determined
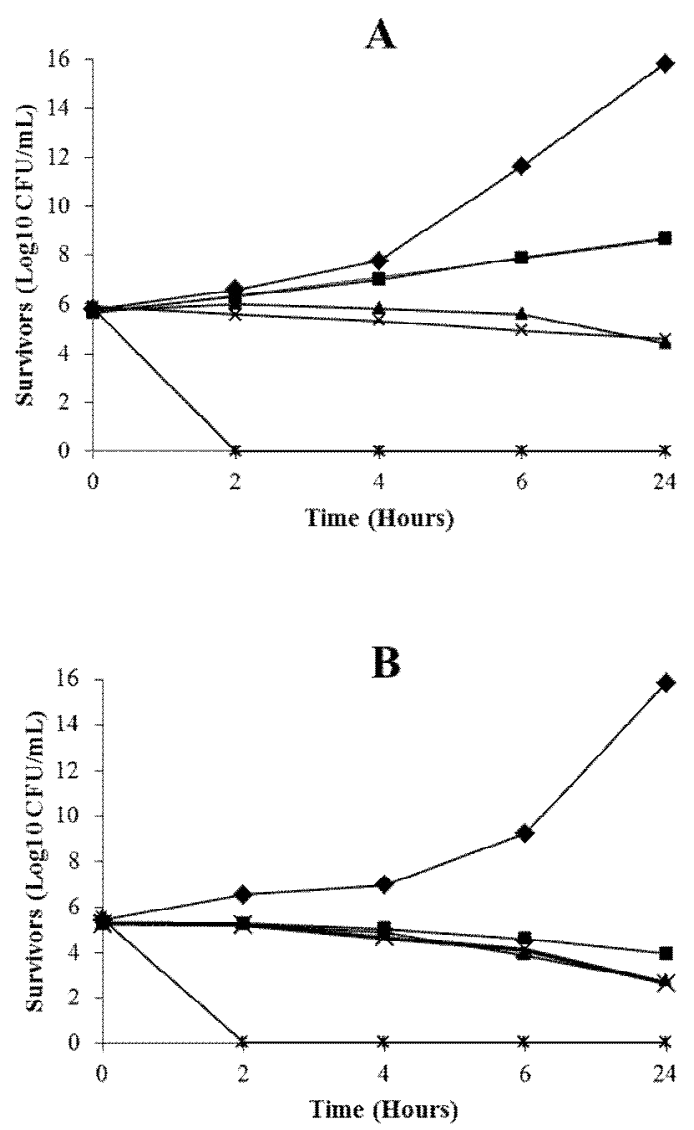

Figure 1: In vitro bactericidal activity of Streptomyces sp. SRF1 culture filtrate extract against MRSA DMST 20651 (A) and MSSA DMST 2933 (B) at concentrations of $0.09 \mathrm{mg} / \mathrm{mL}(0.5 \times \mathrm{MIC}), 0.195$ $\mathrm{mg} / \mathrm{mL}(1 \times \mathrm{MIC})$, and $0.39 \mathrm{mg} / \mathrm{mL}(2 \times \mathrm{MIC})$ compared to an untreated control and tetracycline (0.195 mg/mL). : : untreated control; $\mathbf{\square}: 0.5 \times$ MIC; $\boldsymbol{\Delta}: 1 \times \mathrm{MIC} ; \quad \mathbf{x}: 2 \times \mathrm{MIC} ; *$ : tetracycline showed that the culture filtrate extract and standard tetracycline antibiotic were bactericidal against both MSSA DMST 2933 and MRSA DMST 20651. At $0.5 \times$ MIC $(0.09 \mathrm{mg} / \mathrm{mL})$, the extract was able to reduce viable cell counts of both $S$. aureus strains by more than $3 \log _{10}$ during within $6 \mathrm{~h}$. At concentrations of $1 \times \mathrm{MIC}$ (0.195 $\mathrm{mg} / \mathrm{mL})$ and $2 \times$ MIC $(0.39 \mathrm{mg} / \mathrm{mL})$ also resulted in bactericidal activity against both $S$. aureus strains by $6 \mathrm{~h}$, with lower viable cell counts than at $0.5 \times$ MIC. After $24 \mathrm{~h}$ incubation with $1 \times$ MIC $(0.195 \mathrm{mg} / \mathrm{mL})$ and $2 \times$ MIC $(0.39$ $\mathrm{mg} / \mathrm{mL}$ ) levels of the extract, some of the treated bacteria remained viable but a $10 \log _{10} \mathrm{CFU} / \mathrm{mL}$ reduction in viability of both MSSA and MRSA had occurred (Figure 1). These results indicate that the extract exhibited concentration- and time-dependent bactericidal activity.

\section{Morphological features}

The effect of Streptomyces sp. SRF1 culture filtrate extract on the morphology of MSSA DMST 2933 and MRSA DMST 20651 cells was investigated by SEM. Treatment of $S$. aureus with 1 x MIC levels of extract $(0.195 \mathrm{mg} / \mathrm{mL})$ induced morphological alterations in the bacterial cells. MSSA DMST 2933 bacterial cells became bloated and crushed after $4 \mathrm{~h}$ treatment. Also, some bacterial cells showed cavities and others were lysed (Figure 2B). Similar changes were observed following tetracycline treatment (concentration equal to $1 \times \mathrm{MIC}$ of the extract) (Figure 2C). Untreated control cells did not show any alterations in cell morphology (Figure 2A). In MRSA DMST 20651 treated with extract for $4 \mathrm{~h}$, 
some cells were bloated and crushed, cell surfaces were disrupted and broken, and some cells were lysed (Figure 2E). Similar morphological alterations occurred when MRSA was treated with tetracycline at a concentration of 1 x MIC (Figure 2F). Untreated MRSA cells did not appear damaged (Figure 2D).

\section{Anti-breast cancer cell activity}

The effects of various concentrations (1 - 500 $\mu \mathrm{g} / \mathrm{mL}$ ) of Streptomyces sp. SRF1 culture filtrate extract on the cell viability of breast cancer cell line MCF-7 were investigated using the SRB assay. High concentrations of extract reduced the viability of MCF-7 cells more than lower concentrations. Incubation time also directly affected cell viability compared with the control (Figure 3). The $\mathrm{IC}_{50}$ of the extract against MCF-7 cells was $471.33 \pm 52.82,391.67 \pm 20.58$ and $211.67 \pm 33.95 \mu \mathrm{g} / \mathrm{mL}$ for 24,48 and $72 \mathrm{~h}$, respectively. The highest Emax value, $71.53 \pm$ 5.13 , was recorded at an exposure time of $72 \mathrm{~h}$, followed by $48.91 \pm 6.10$ and $57.53 \pm 5.41$ for 24 and $48 \mathrm{~h}$, respectively. These results indicate that the extract exhibited concentration - and time - dependent cytotoxic activity against the MCF-7 cell line.

\section{DISCUSSION}

Bacteria in the Streptomyces genus are well known to have bioactive secondary metabolite producing activity, these products widely used by the pharmaceutical industry for their antimicrobial, antiviral [20] and anticancer activities [9]. In previous studies, we demonstrated that Streptomyces sp. SRF1, isolated from a rice field, inhibits the growth of phytopathogenic fungi and the food-borne bacterial pathogen Bacillus cereus under in vitro conditions $[14,15]$. In the present work, the activity of this culture filtrate extract was investigated against other important bacterial strains and the breast cancer cell line MCF-7. The results demonstrate that the extract has activity against 4 strains of Staphylococcus aureus, but no activity against any of the test strains of Gram negative bacteria. These results may reflect the mode of antibacterial action of the extract. Because Gram negative and Gram positive bacteria differ in their cell wall structure, they have different characteristics in terms of available target site and molecule adsorption and uptake [21]

The results show that the pathogens MSSA DMST 2933, MRSA DMST 4738, MRSA DMST 20651, and MRSA DMST 20654 were quite sensitive to the culture filtrate extract of Streptomyces sp. SRF1. Of these four strains, MRSA DMST 20651 had the highest resistance to ciprofloxacin and tetracycline antibiotics. Next, time - kill assays were performed with the culture filtrate extract on MRSA DMST 20651 and MSSA DMST 2933. These results indicate the culture filtrate extract is bactericidal, reducing viable cell counts of the tested $S$. aureus strains by more than $3 \log _{10}$ in $6 \mathrm{~h}$. Larger reductions in viable cell count (more than $10 \log _{10}$ ) were observed when the extract concentration and exposure time were increased (Figure $1 \mathrm{~A}$ and $1 \mathrm{~B}$ ). These results indicate that the culture filtrate extract kills $S$. aureus in both a concentration - and time dependent manner. This result correlate with the
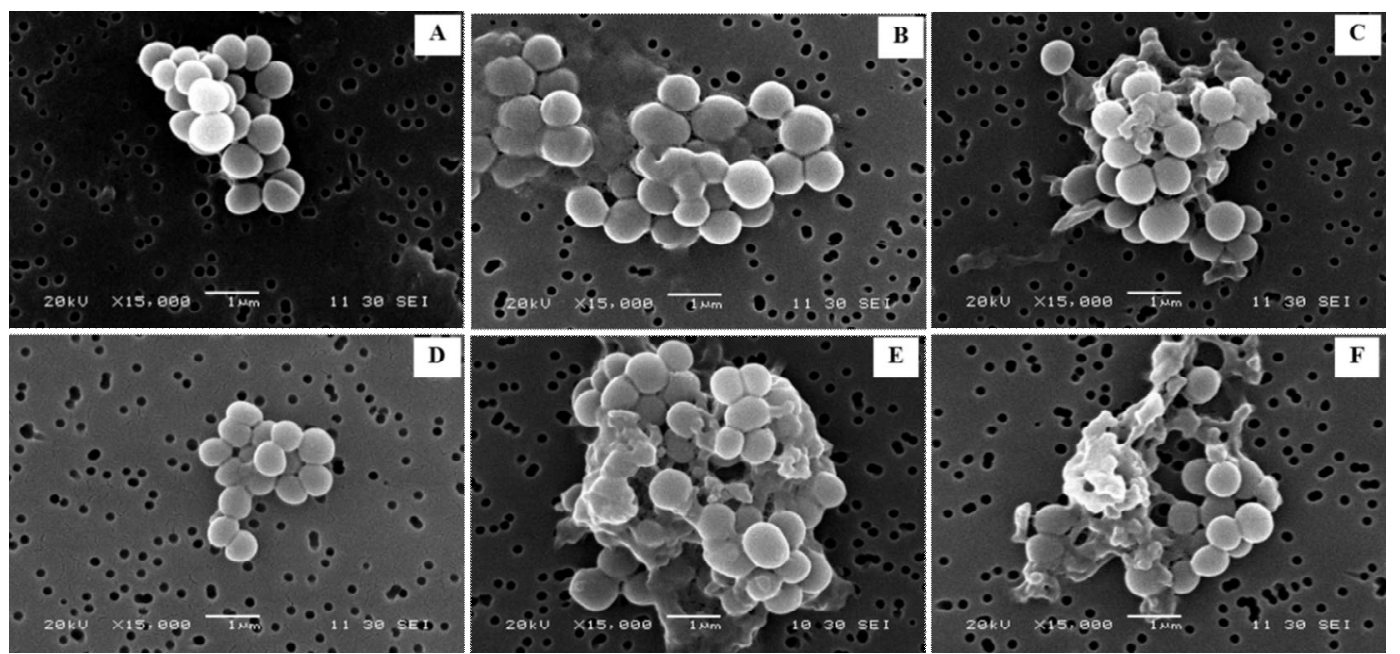

Figure 2: Scanning electron micrographs of S. aureus (MSSA) DMST 2933 (A - C) and S. aureus (MRSA) DMST 20651 (D - F) after treatment with Streptomyces sp. SRF1 culture filtrate extract at $1 \times$ MIC $(0.195 \mathrm{mg} / \mathrm{mL})(B$ and $\mathrm{E})$, and the antibiotic tetracycline at $0.195 \mathrm{mg} / \mathrm{mL}(\mathrm{C}$ and $\mathrm{F})$ for $4 \mathrm{~h}$ as compared with untreated controls $(\mathrm{A}$ and D) 

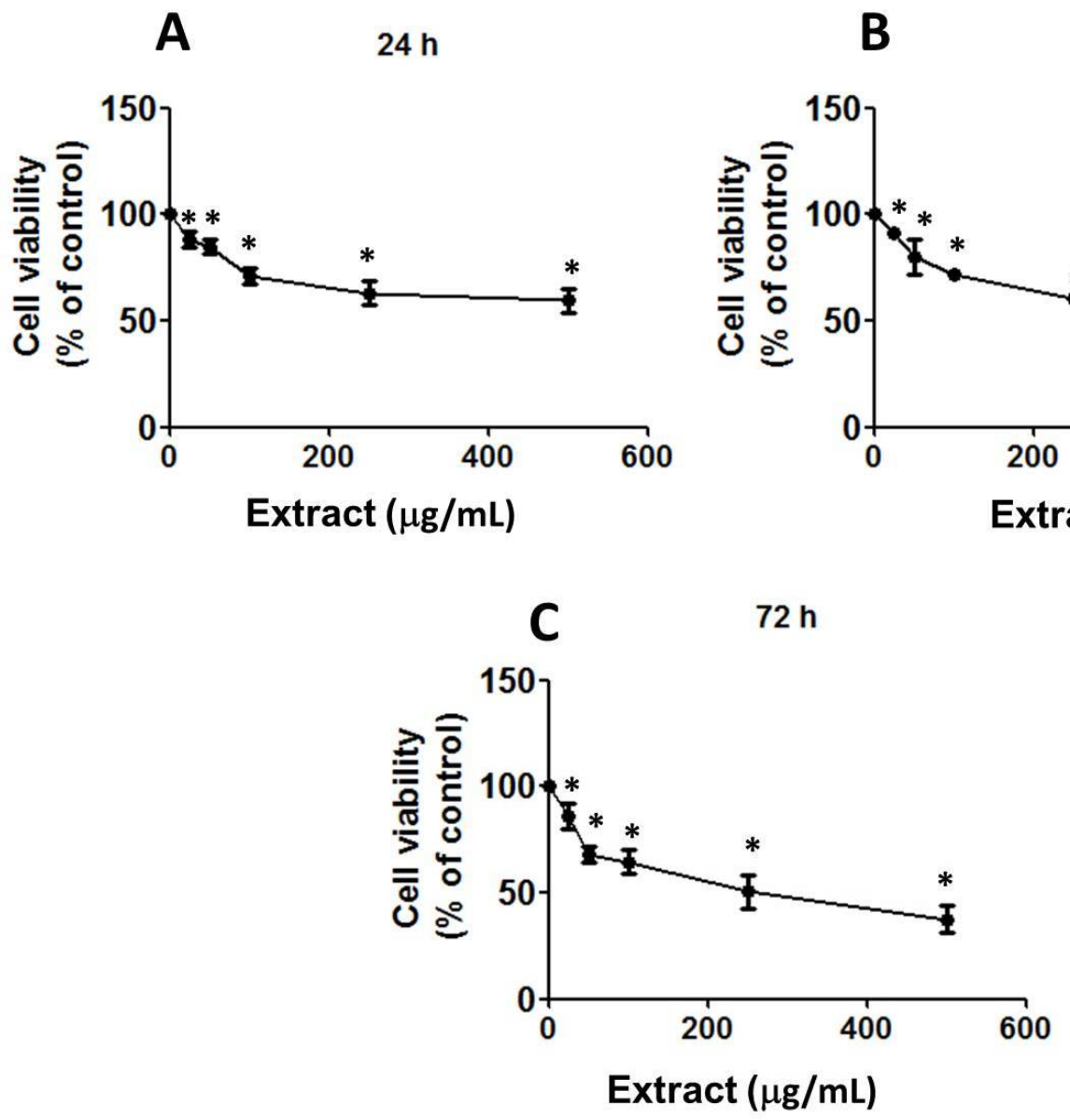

$48 \mathrm{~h}$

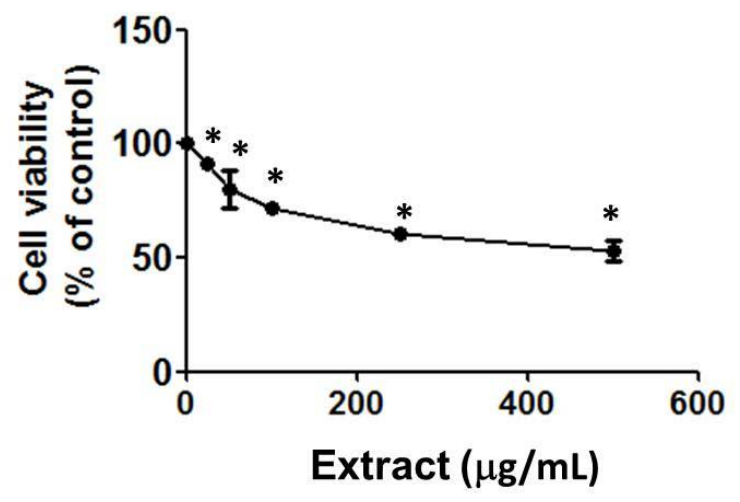
MCF-7. MCF-7 cells were treated with various concentrations of $1-500 \mu \mathrm{g} / \mathrm{mL}$ for $24-72 \mathrm{~h}$. The MCF-7 cell proliferation was measured by the SRB assay after treatment. The experiment was done in three independent experiments. The results are presented as percentage of control, and represent mean \pm SEM values. ${ }^{*} p<0.05$ vs. untreated control groups

opinion of Iniyan et al [22], who demonstrated that the phenolic compound $\mathrm{T} 1$ isolated from a marine-derived actinomycete Micromonospora sp. ICN36 inhibited the growth of MRSA and MSSA at low concentrations (MIC values of 0.5 and $0.25 \mu \mathrm{g} / \mathrm{mL}$, respectively). Moreover, the $4 \mathrm{x}$ MIC of the phenolic compound T1 showed bactericidal activity against MRSA after $4 \mathrm{~h}$ exposure [22].

To determine if the culture filtrate extract might exert its antibacterial activity by targeting the cell wall, we examined the effects of the extract on Staphylococcus aureus using SEM. At 1 x MIC, the extract altered the surface appearance and morphology of both MSSA and MRSA cells. Observed changes included cell bloating, a crushed appearance, cell surface disruption, and lysis. These cell alteration effects may be due to bioactive constituents in the culture filtrate extract disrupting peptidoglycan biosynthesis [23,24]. Many bioactive compounds produced by Streptomyces spp., for example phenolic compounds and antibiotics, have been shown to alter cell surface appearance. Previous observations include wrinkling of the cell surface and cell shrinkage $[22,24,25]$.

Results from the anti-breast cancer assay clearly indicate that Streptomyces sp. SRF1 culture filtrate extract has concentration- and timedependent cytotoxic activity against the MCF-7 cell line. This effect may be due to bioactive compounds present in the extract. Bioactive compounds isolated previously from Streptomyces spp. have been reported to inhibit the activation of survival signaling pathways in cancer cells [26,27]. Ser et al [11] demonstrated that a fermentation extract derived from $S$. pluripotens MUSC 137 had both significant antioxidant activity and significant cytotoxic activity. Several cancer cell lines were shown to be susceptible including MCF-7. S. parvus extract has also been shown to be active against breast cancer cell lines [28]. Isolation and structure elucidation of the compounds 
responsible for the bioactivities of Streptomyces $\mathrm{sp}$. SRF1 culture filtrate extract are now underway in our laboratory.

\section{CONCLUSION}

The findings of this work show that Streptomyces sp. SRF1 culture filtrate extract has bactericidal activity against staphylococci bacteria including methicillin-resistant $S$. aureus. Furthermore, the extract also exerts activity against MCF-7 breast cancer cell line. Thus, Streptomyces sp. SRF1 culture filtrate extract, after appropriate further investigation, may yield antibacterial and anticancer drug candidates. Further studies will now focus on isolating the compounds responsible for the observed bioactivities and elucidating their structures.

\section{DECLARATIONS}

\section{Acknowledgement}

The authors are grateful to Mahasarakham University Faculty of Medicine for equipment support and language-editing assistance, and Mahasarakham University Faculty of Science for provision of laboratory space and equipment. B. Buranrat is grateful to Thailand Research Fund (grant no. MRG6080071). P. Seephonkai is grateful to the Center of Excellence for Innovation in Chemistry for support (no. PERCH$\mathrm{CIC})$.

\section{Conflict of Interest}

No conflict of interest associated with this work.

\section{Contribution of Authors}

The authors declare that this work was done by the authors named in this article and all liabilities pertaining to claims relating to the content of this article will be borne by them.

\section{Open Access}

This is an Open Access article that uses a funding model which does not charge readers or their institutions for access and distributed under the terms of the Creative Commons Attribution License (http://creativecommons.org/licenses/by/ 4.0) and the Budapest Open Access Initiative (http://www.budapestopenaccessinitiative.org/rea d), which permit unrestricted use, distribution, and reproduction in any medium, provided the original work is properly credited.

\section{REFERENCES}

1. Ilic SB, Konstantinovic SS, Todorovic ZB, Lazic $M L$, Veljkovic VB, Jokovic $N$, Radovanovic $B C$. Characterization and antimicrobial activity of the bioactive metabolites in Streptomyces isolates. Microbiol 2007; 76: 421-428.

2. Subramani R, Aalbersberg W. Marine actinomycetes: an ongoing source of novel bioactive metabolites. Microbiol Res 2012; 167: 571-580.

3. Taddei A, Rodríguez MJ, Márquez-Vilchez E, Castelli C. Isolation and identification of Streptomyces spp. from Venezuelan soils: morphological and biochemical studies. I. Microbiol Res 2006; 161(3): 222-231.

4. Berdy J. Bioactive microbial metabolites. J Antibiot 2005; 58: 1-26.

5. Rehm S, Han S, Hassani I, Sokocevic A, Jonker HR, Engels JW, The high resolution NMR structure of parvulustat (Z-2685) from Streptomyces parvulus $\mathrm{FH}$ 1641: comparison with tendamistat from Streptomyces tendae 4158. ChemBioChem 2009; 10: 119-127.

6. Crnovcic I, Vater $J$, Keller $U$. Occurrence and biosynthesis of $C$-demethyl actinomycins in actinomycinproducing Streptomyces hrysomallus and Streptomyces parvulus. J Antibiot 2013; 66: 211-218.

7. Valan Arasu $M$, Duraipandiyan $V$, Agastian $P$, Ignacimuthu $S$. In vitro antimicrobial activity of Streptomyces spp. ERI-3 isolated from Western Ghats rock soil (India). J Mycol Med 2009; 19: 22-28.

8. Higginbotham SJ, Murphy $C D$. Identification and characterization of a Streptomyces sp. isolate exhibiting activity against anti-methicillin resistant Staphylococcus aureus. Microbiol Res 2010; 165: 82-86.

9. Yip WK, Cheenpracha S, Chang LC, Ho CC, Seow HF. Anti-proliferative and anti-invasive properties of a purified fraction from Streptomyces sp. H7372. Int $\mathrm{J}$ Oncol 2010; 37: 1229-1241.

10. Sharma D, Kaur $T$, Chadha BS, Manhas $R K$. Antimicrobial activity of actinomycetes against multidrug resistant Staphylococcus aureus, E. coli and various other pathogens. Trop J Pharm Res 2011; 10(6): 801808.

11. Ser HL, Ab Mutalib NS, Yin WF, Chan KG, Goh BH, Lee $L H$. Evaluation of antioxidative and cytotoxic activities of Streptomyces pluripotens MUSC 137 isolated from mangrove soil in Malaysia. Front Microbiol 2015; 6: 1398: doi: 10.3389/fmicb.2015.01398

12. Lee MJ, Lim DS, Lee MS, Yoon WH, Kim CH. Characterization of Streptomyces sp. AMLK-135 producing anti-MRSA antibiotics. J Microbiol Biotechnol 1997; 7(6): 397-401.

13. Naorungrote $S$, Chunglok $W$, Lertcanawanichakul $M$, Bangrak $P$. Actinomycetes producing anti-methicillin resistant Staphylococcus aureus from soil samples in Nakhon Si Thammarat. Walailak J Sci Tech 2011; 8(2): 131-138.

14. Sangdee $A$, Kornphachara $S$, Srisawat $N$. In vitro screening of antagonistic activity of soil Streptomyces

Trop J Pharm Res, November 2017; 16(11): 2733 
against plant pathogenic fungi and assessment of its characters, J Agri Tech 2016; 12: 173-185.

15. Sangdee K, Pimta J, Seephonkai P, Sangdee A. Antibacterial activity, time-kill profile and morphological effects of Streptomyces sp. SRF1 extracts against the foodborne pathogen Bacillus cereus. Int $J$ ChemTech Res 2016; 9(6): 709-717.

16. Sangdee K, Nakbanpote $W$, Sangdee A. Isolation of the entomopathogenic fungal strain Cod-MK1201 from a cicada nymph and assessment of its antibacterial activities. Int J Med Mushrooms 2015; 17(1): 51-63.

17. Thammawat S, Sangdee K, Sangdee A. Time-kill profiles and cell-surface morphological effects of crude Polycephalomyces nipponicus Cod-MK1201 mycelial extract against antibiotic-sensitive and - resistant Staphylococcus aureus. Trop J Pharm Res 2017; 16(2): 407-412.

18. Buranrat $B$, Senggunprai $L$, Prawan $A$, Kukongviriyapan V. Simvastatin and atorvastatin as inhibitors of proliferation and inducers of apoptosis in human cholangiocarcinoma cells. Life Sci 2016; 153: 41-49.

19. Sangdee $K$, Buranrat $B$, Naksuwankul $K$, Jaihan $P$, Sangdee A. Antibacterial and anti-breast cancer cell line activities of Sanghuangporus sp.1 extracts. Trop J Pharm Res 2017; 16(3): 613-620.

20. Sacramento DR. Coelho RRR, Wigg MD, de Toledo Luna Linhares LF, dos Santos GM, de Azevedo Soares Semêdo LT, da Silva AJR. Antimicrobial and antiviral activities of an actinomycete (Streptomyces sp.) isolated from a Brazilian tropical forest soil. World J Microbiol Biotechnol 2004; 20: 225-229.

21. Russell $A D$. Similarities and differences in the responses of microorganisms to biocides. J Antimicrob Chemother 2003; 52: 750-763.
22. Iniyan AM, Joseph FRS, Kannan RR, Vincent SGP. AntiMRSA potential of phenolic compound isolated from a marine derived actinomycete Micromonospora $s p$. ICN36. Indian J Mar Sci 2016; 45(10): 1279-1287.

23. Cushnie TPT, O'Driscoll NH, Lamb AJ. Morphological and ultrastructural changes in bacterial cells as an indicator of antibacterial mechanism of action. Cell Mol Life Sci 2016; 73: 4471-4492.

24. Iniyan AM, Mary TRJ, Joseph FJRS, Kannan RR, Vincent SGP. Cell wall distracting anti-Methicillin-resistant Staphylococcus aureus compound PVI331 from a marine sponge associated Streptomyces. J Appl Biomed. 2016; http://dx.doi.org/10.1016/j.jab.2016.04. 003.

25. Mehta S, Singh C, Plata KB, Chanda PK, Paul A, Riosa $S$, Rosato RR, Rosato AE. B-Lactams increase the antibacterial activity of daptomycin against clinical methicillin-resistant Staphylococcus aureus strains and prevent selection of daptomycin-resistant derivatives. Antimicrob Agents Chemother 2012; 56(12): 6192-6200.

26. Lopaczynski W, Zeisel SH. Antioxidants, programmed cell death, and cancer. Nutr Res 2001; 21: 295-307.

27. Chen HM, Wu YC, Chia YC, Chang FR, Hsu HK, Hsieh YC, Chen CC, Yuan SS. Gallic acid, a major component of Toona sinensis leaf extract, contains a ROS-mediated anti-cancer activity in human prostate cancer cells. Cancer lett 2009; 286: 161-171.

28. Abd-Elnaby $H$, Abo-Elala $G$, Abdel-Raouf $U, A b d$ elwahab A, Hamed M. Antibacterial and anticancer activity of marine Streptomyces parvus: optimization and application. Biotechnol Biotechnol Equip 2015; 30(1): 180-191. 